\title{
How does Oedipoda germanica (Orthoptera: Acrididae) cope on the northern edge of its distribution? A demographical study of a completely isolated population
}

\author{
StanislaV RADA ${ }^{1}$, Lucie ŠTĚPÁNOVÁ ${ }^{1}$, JAN LOSÍK $^{1}$, JAN ŠIPOŠ ${ }^{2,3}$, JAROSLAV HOLUŠÁ ${ }^{4}$ and TomÁŠ KURAS ${ }^{1}$ \\ ${ }^{1}$ Department of Ecology and Environmental Sciences, Faculty of Science, Palacký University Olomouc, Šlechtitelů 27, \\ 78371 Olomouc - Holice, Czech Republic; e-mails: stanislav.rada@seznam.cz; polesanka@gmail.com; jan.losik@gmail.com; \\ kurast@seznam.cz \\ ${ }^{2}$ Department of Biology and Ecology, Faculty of Science, University of Ostrava, Chittussiho 10, 71000 Slezská Ostrava, Czech \\ Republic; e-mail: jsipos@seznam.cz \\ ${ }^{3}$ Global Change Research Centre, Academy of Sciences of the Czech Republic, Bělidla 986/4a, 60300 Brno, Czech Republic \\ ${ }^{4}$ Department of Forest Protection and Entomology, Faculty of Forestry and Wood Sciences, Czech University of Life Sciences, \\ Kamýcká 1176, 16521 Praha 6 - Suchdol, Czech Republic; e-mail: HolusaJ@seznam.cz
}

Key words. Orthoptera, Acrididae, Oedipoda germanica, endangered grasshopper, population size, survival, temperature

\begin{abstract}
We studied a population of the Red-winged grasshopper Oedipoda germanica, which is a highly stenotypic and endangered species in Central Europe. The locality studied is completely isolated and at the northern limit of this species distribution (north-west of the Czech Republic). We used capture-mark-recapture in 3 consecutive years (2008-2010). We estimated the total population size using POPAN software to be 136 adults in 2008, 70 in 2009 and 122 in 2010 . Estimated daily survival rate $(\Phi)$ ranged from 0.950 to 0.987. We constructed linear mixed models to test for apparent survival in relation to temperature data. Temperatures (i.e. mean air temperature and maximum air temperature) were found to have significant effects on survival. The population studied is small, isolated and thus threatened by extinction, as are other $O$. germanica populations at the northern limit of their distribution. The preservation of indigenous populations in their localities can be achieved by active management, including the removal of shrubs and trees.
\end{abstract}

\section{INTRODUCTION}

The Red-winged grasshopper, Oedipoda germanica (Latreille, 1804) is a highly specialized (Wagner, 2000) and sedentary species (Zöller, 1995; Wagner, 2000). It ranges from the Pyrenees Mts in the west to the Crimea in the east, with the main part of its distribution in southern Europe (Wagner, 2000). The northern limit of this species distribution runs through the middle of Germany (northern Westphalia, Thuringia, south of Saxony-Anhalt) and the western part of the Czech Republic (Wagner, 2000; Holuša et al., 2009). The northern part of this species distribution is depicted in Fig. 1. Due to its habitat requirements, this species is threatened in the northern part of its distribution. $O$. germanica is considered to be critically endangered in both Germany (Ingrisch \& Köhler, 1998a; Maier, 2003) and the Czech Republic (Holuša \& Kočárek, 2005; Holuša et al., 2009).

This species is associated with xerothermic sites with minimal vegetation cover, typically sparse steppes or rocky slopes with a southern orientation, which suit the xerophilous and thermophilous requirements of this species (Wagner \& Berger, 1996; Wagner, 2000). The imagoes may occasionally occur in dense vegetation, but will immediately return to areas with bare ground or rock (Zöller, 1995). O. germanica needs high temperatures for its reproduction and development (Wagner, 2000; Wagner et al., 2005) and at their northern limit these conditions can be found pre- dominantly on southern slopes with low vegetation cover. Large part of recently occupied habitats is of anthropogenic origin or preserved by anthropogenic management (e.g. quarries or grazed hillsides; Wagner, 2000; Holuša et al., 2009).

The occurrence of $O$. germanica in the Czech Republic is restricted to several localities on Bohemian Karst [Český kras] near Prague and in the Central Bohemian Uplands [České stř̌edohoří] in north-western Bohemia (Fig. 2). On Bohemian Karst, there are 7 localities. In the central Bohemian uplands, there is now only a single locality on Košt'ál Hill as this species went extinct at other localities in this area during the $20^{\text {th }}$ century (Holuša et al., 2009). Košt'ál Hill is $60 \mathrm{~km}$ away from the closest occupied locality. The maximum distance that $O$. germanica is recorded migrating in the literature is $500 \mathrm{~m}$ for a male (Zöller, 1995) and $204 \mathrm{~m}$ for a female (Wagner, 2000) and for the majority of individuals is much less, with a median life-long dispersal distance of around $30 \mathrm{~m}$ (Wagner, 2000; Zöller, 1995). Therefore, Koštál hill hosts a completely isolated and the northern-most population of $O$. germanica in the Czech Republic.

Populations on the edge of a species distribution are more likely to be threatened by extinction than central populations (Soulé, 1973; Lesica \& Allendorf, 1995; Thomas et al., 1998). They often exist in less suitable conditions (Lesica \& Allendorf, 1995) or are restricted to small areas of fa- 


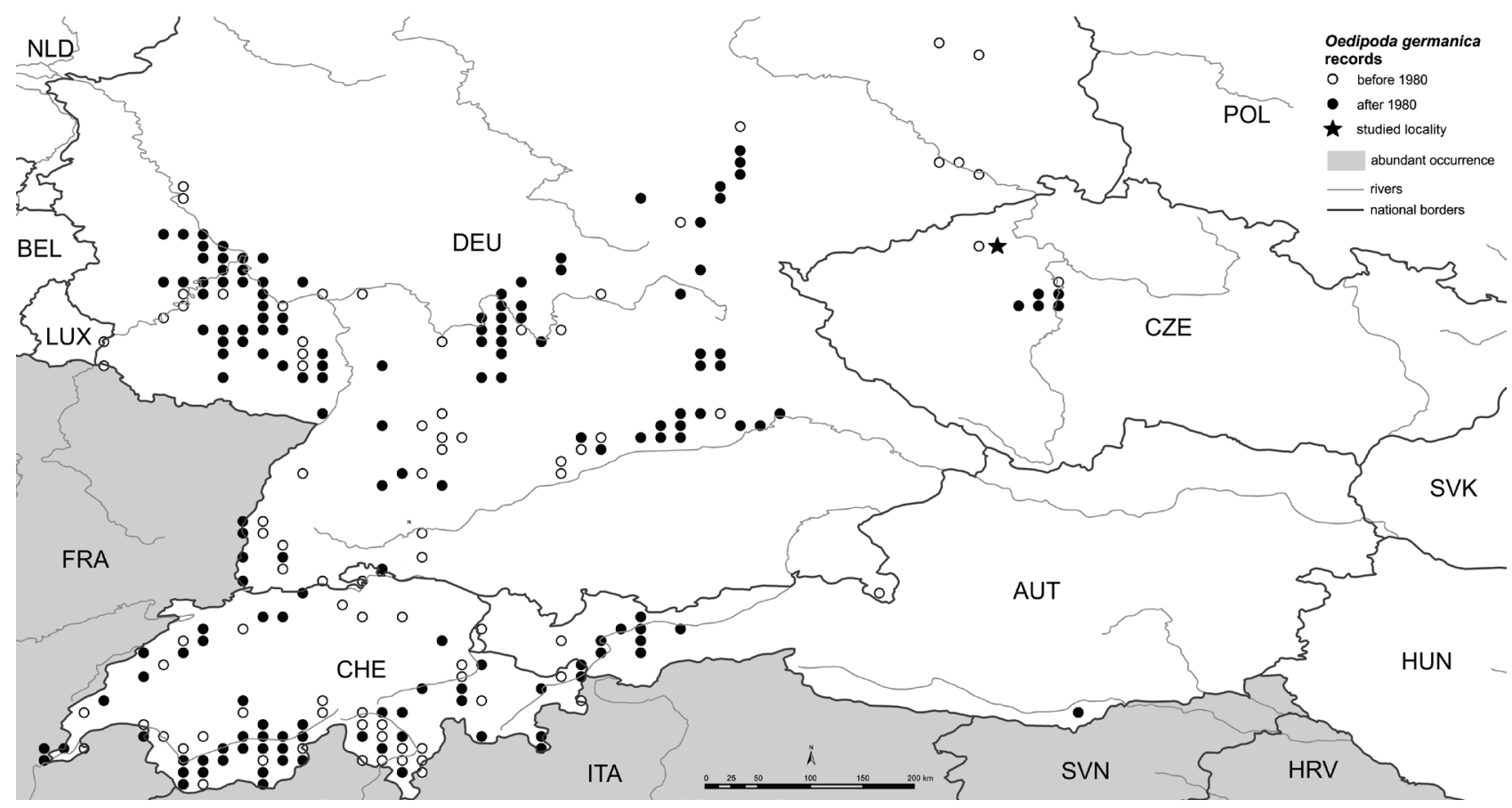

Fig. 1. Map showing the distribution of Oedipoda germanica in central Europe (according to Thorens \& Nadig, 1997; Heller et al., 1998; Maas et al., 2002; Holuša et al., 2009; Zuna-Kratky, 2011). Position of the locality studied is indicated by a star.

vourable habitat (Lesica \& Allendorf, 1995; Thomas et al., 1998). Isolation is common in such populations and also typical in species with reduced mobility (Lesica \& Allendorf, 1995). Small population sizes and isolation of peripheral populations causes loss of genetic variation and related detrimental processes (Johannesson \& André, 2006). On the other hand, the peripheral populations are of substantial conservation value in terms of gene-pool protection as well as evolution and future speciation, since they often differ genetically from central populations (Soulé, 1973; Lesica \& Allendorf, 1995; Johannesson \& André, 2006).

The locality of Oedipoda germanica on Košt’ál Hill hosts an isolated and unique population. Our aims were therefore: (1) To determine the demographic parameters of this population, including mean daily survival rate $(\Phi)$, not previously recorded for this species; (2) for the first time, to test the effect of temperature on survival of $O$. germanica adults; (3) based on our findings and published data, to propose practical measures for protecting and conserving this species.

\section{METHODS}

\section{Study site}

We studied a single population of $O$. germanica on Koštél Hill in the south-western part of the Central Bohemian Uplands [České středohoří] (north-western Bohemia, Czech Republic). Košt'ál Hill (481 m a.s.1.; 50²9'25.16"N, 1359'4.93"E; see Fig. $1,2)$ is constituted of basaltic rocks with steep slopes and crags

TABLE 1. Dates when sampled with numbers of newly caught and recaptured grasshoppers and temperature. The temperatures (mean temp. and mean of maximum temp.) are those for the preceding sampling period with the standard error in brackets. We did not use the last sampling periods, because in each year no grasshoppers were recorded on the last sampling occasion.

\begin{tabular}{|c|c|c|c|c|c|c|c|c|}
\hline \multirow{5}{*}{ 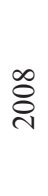 } & Date & $22^{\text {nd } J u l y ~}$ & $4^{\text {th }}$ Aug & $26^{\text {th }}$ Aug & $10^{\text {th }}$ Sept & $26^{\text {th }}$ Sept & $20^{\text {th }}$ Oct & $4^{\text {th }}$ Nov \\
\hline & New catches & 13 & 4 & 18 & 20 & 13 & 3 & 0 \\
\hline & Recaptures & 0 & 0 & 5 & 8 & 7 & 1 & 0 \\
\hline & Mean temp. & $\mathrm{n} / \mathrm{a}$ & $18.88(0.85)$ & $15.55(0.66)$ & $15.07(0.58)$ & $6.71(0.86)$ & $8.09(0.51)$ & $\mathrm{n} / \mathrm{a}$ \\
\hline & Max. temp. & $\mathrm{n} / \mathrm{a}$ & $25.23(1.24)$ & $20.99(1.01)$ & $21.01(0.80)$ & $10.24(1.24)$ & $12.04(0.61)$ & $\mathrm{n} / \mathrm{a}$ \\
\hline \multirow{5}{*}{ 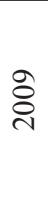 } & Date & $14^{\text {th }}$ July & $23^{\text {rd }}$ July & $9^{\text {th }}$ Aug & $24^{\text {th }}$ Aug & $8^{\text {th }}$ Sept & $28^{\text {th }}$ Sept & $12^{\text {th }}$ Oct \\
\hline & New catches & 4 & 3 & 14 & 12 & 7 & 11 & 0 \\
\hline & Recaptures & 0 & 4 & 2 & 10 & 9 & 5 & 0 \\
\hline & Mean temp. & $\mathrm{n} / \mathrm{a}$ & $16.93(1.22)$ & $13.39(0.50)$ & $16.36(0.63)$ & $15.17(0.91)$ & $13.01(0.54)$ & $\mathrm{n} / \mathrm{a}$ \\
\hline & Max. temp. & $\mathrm{n} / \mathrm{a}$ & $24.34(1.48)$ & $22.82(0.82)$ & $22.71(1.01)$ & $21.66(1.19)$ & $18.19(0.74)$ & $\mathrm{n} / \mathrm{a}$ \\
\hline \multirow{5}{*}{$\stackrel{\circ}{\stackrel{\circ}{\sim}}$} & Date & $5^{\text {th }}$ July & $16^{\text {th }}$ July & $10^{\text {th }} \mathrm{Aug}$ & $7^{\text {th }}$ Sept & $23^{\text {th }}$ Sept & $14^{\text {th }}$ Oct & $30^{\text {th }}$ Oct \\
\hline & New catches & 4 & 23 & 33 & 15 & 13 & 0 & 0 \\
\hline & Recaptures & 0 & 2 & 14 & 11 & 10 & 1 & 0 \\
\hline & Mean temp. & $\mathrm{n} / \mathrm{a}$ & $20.95(1.40)$ & $15.53(0.56)$ & $13.00(0.83)$ & $10.53(0.51)$ & $6.63(0.49)$ & $\mathrm{n} / \mathrm{a}$ \\
\hline & Max. temp. & $\mathrm{n} / \mathrm{a}$ & $28.15(1.60)$ & $21.57(0.88)$ & $18.34(1.00)$ & $14.93(0.80)$ & $9.79(0.60)$ & $\mathrm{n} / \mathrm{a}$ \\
\hline
\end{tabular}




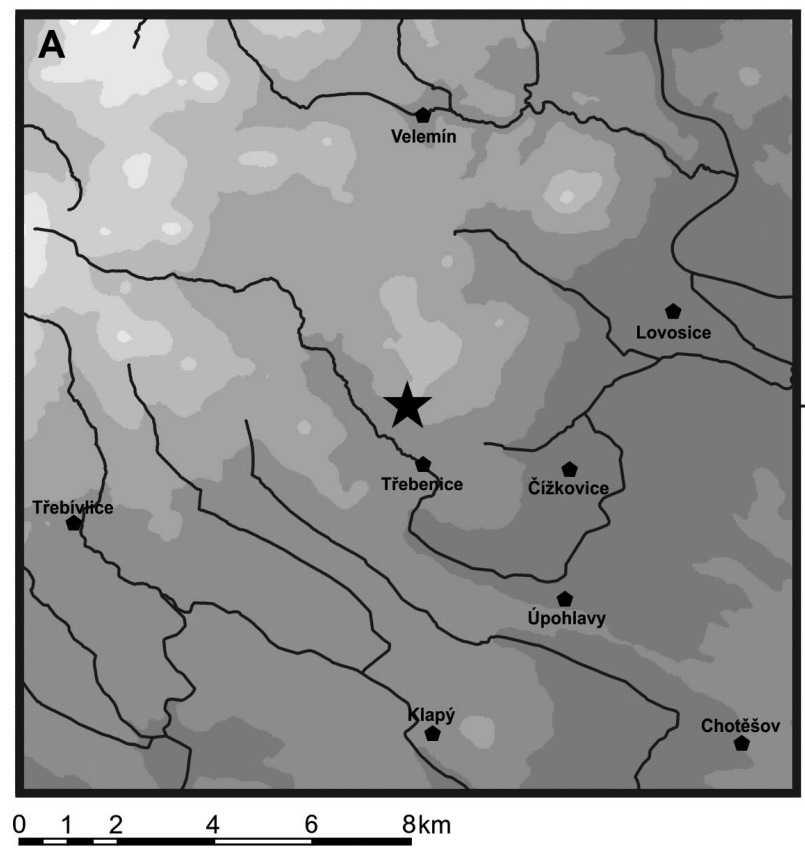

Altitude (m a.s.I.)

$<200$

$201-300$

$301-400$

$501-600$

$>700$

Oedipoda germanica records

water
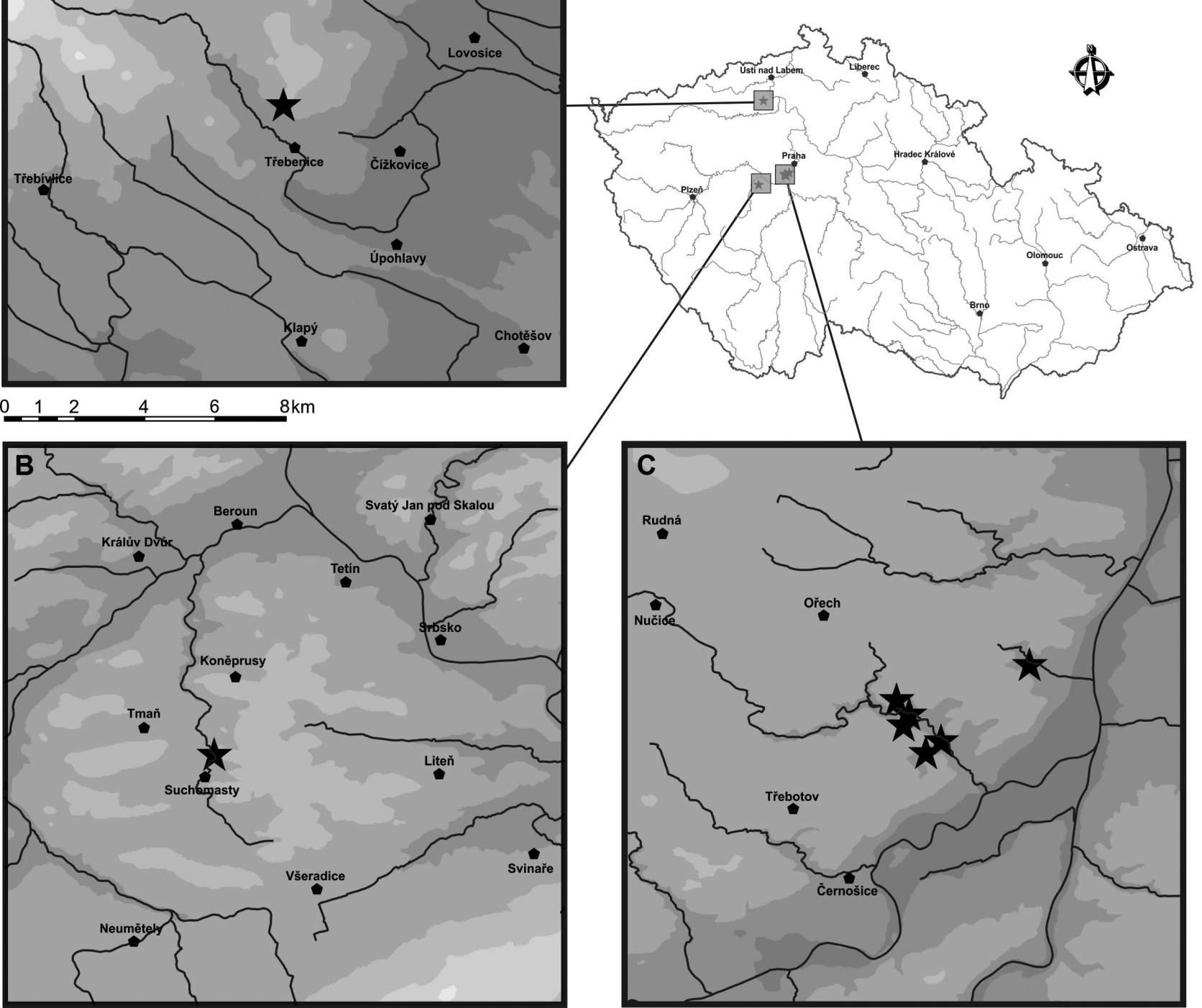

Fig. 2. Map showing the recent distribution of the Oedipoda germanica in the Czech Republic. There are 7 localities on Czech Karst $(B, C), 6$ of them near to each other (C). The locality studied (A) is completely isolated in the Central Bohemian Uplands.

(Fig. 3). The northern part of the hill is covered by forest; the southern part has a rocky character with steppe and forest-steppe mosaic. The south-eastern slope was formerly used as a quarry. Rocks and debris on the southern slopes accumulate a large amount of heat due to their direct exposure to sun shine; hence, the locality is an "island" of warmer microclimate within an otherwise cooler landscape matrix.

Plant and animal communities on Koštál Hill are typically xerothermic and include many protected and threatened species (Kuncová et al., 1999). The occurrence of O. germanica on Košt'ál Hill was recorded for the first time in 1980 (Čejchan, 1980). We measured the current extent of the locality using orthophoto maps (software ArcView) after direct inspection in field. Theoretically, the suitable habitat for $O$. germanica at this locality covers an area of approximately 0.53 ha, however, we were only able to sample an area of 0.25 ha as much of the area was inaccessible because it consists of steep rocks and scarps (see Fig. 3).

\section{Field methods}

In order to assess the demographical parameters of the $O$. germanica population studied, we used capture-mark-recapture (CMR) over a period of 3 years (2008-2010). We used a strip of cloth on a rod to startle the cryptic grasshoppers, which resulted in them displaying their red hindwings and thus revealing their position. We then caught the specimens using an entomological net (40 cm in diameter) and marked them using a Uni Paint Marker. Each individual caught was marked with a unique combination of colours (red, yellow and green) and a particular number of transverse lines (1-9) on its forewings and then immediately released. Recaptures of already marked individuals were recorded. We only marked adult individuals. 


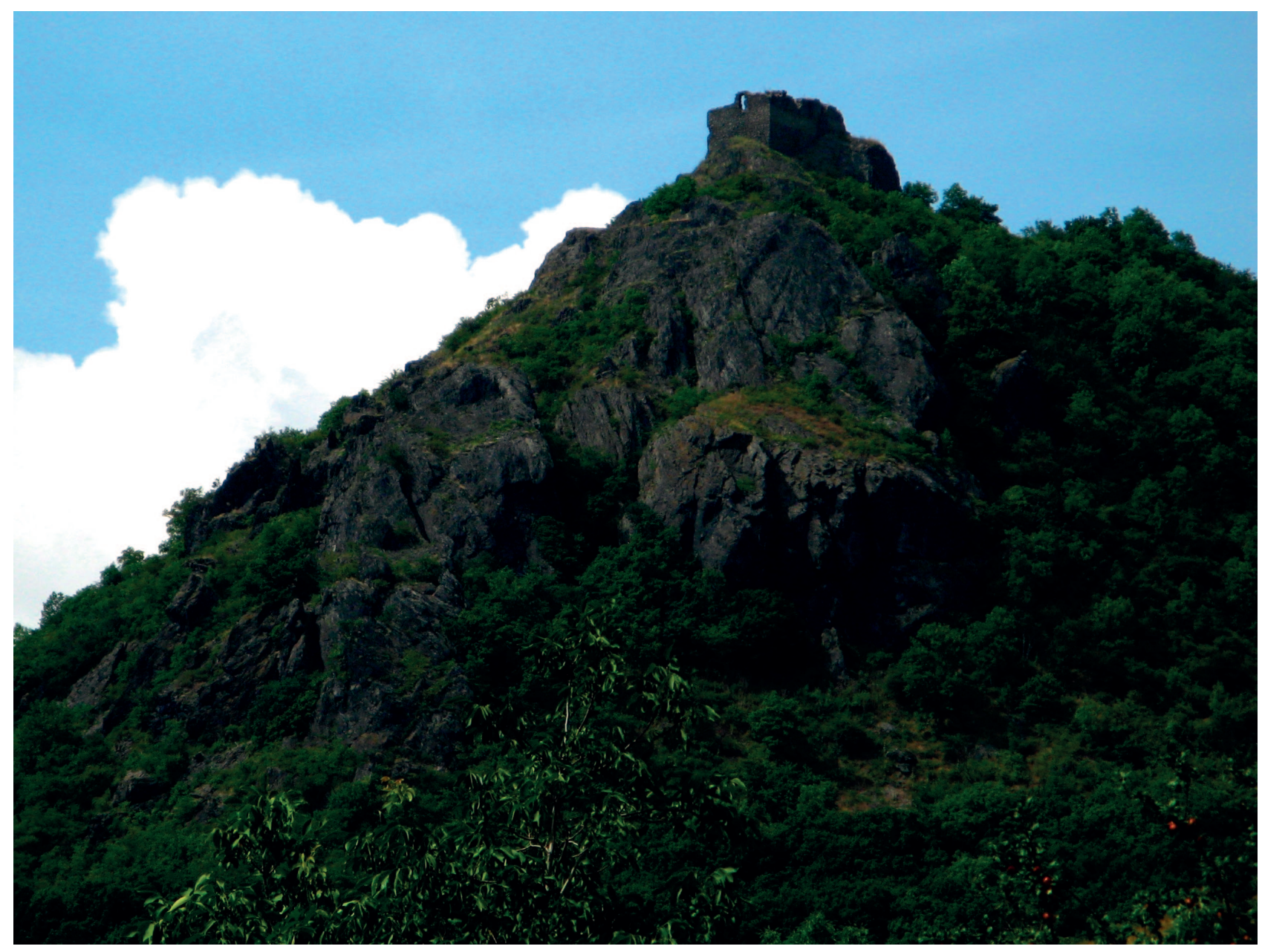

Fig. 3. Koštál Hill, showing the locality of Oedipoda germanica studied.

There were 7 capture occasions each year, the first in July, when the imagoes began to appear and the last at the end of the adults-lifespan when no grasshoppers were recorded at this locality (October/November) (Table 1). Sampling was only done when weather conditions were suitable, i.e. sunny, little wind and high temperatures. Each sampling occasion lasted for from 2.5 to $3 \mathrm{~h}$ always between 10 a.m. and 2 p.m. (Central European Summer Time). By the end of the occasion, catches of already marked individuals often repeated, which indicated sufficient sampling effort.

We recorded temperatures directly at the locality in the first year (2008), but this was prevented thereafter due to an unexpected malfunction of our data logger. Instead of data-logger temperatures, we therefore used climatic data from the nearby meteorological observatory, Milešovka, which is situated $8.2 \mathrm{~km}$ away from the study site. We determined the correlation between temperatures measured simultaneously at both sites (the study locality and meteorological observatory) from the $5^{\text {th }}$ August to the $20^{\text {th }}$ October 2008 . The mean daily temperature correlation was $0.939, \mathrm{R}^{2}=0.882$ and the maximum daily temperature correlation was $0.878, \mathrm{R}^{2}=0.771$. Thus the weather at the two sites is clearly very similar. For the purpose of our analysis is important the synchronic trend in temperature in time (i.e. the differences in temperature between individual days), not the absolute temperature values.

\section{Data analysis}

We estimated the daily survival rate for each sampling period using the software Jolly, model A (Pollock et al., 1990). Model A considers both mortality and immigration in a computing algorithm. Despite the fact that our study site was isolated from any other locality, some animals could still migrate to inaccessible parts of the locality (see Study site). We therefore can only estimate apparent survival $(\Phi)$, i.e. the probability of surviving and remaining in the study area (Lebreton et al., 1992). Based on the mean daily survival rate, we calculated average residence time $T_{m}$ (i.e. average number of days alive) for each year; using equation $T_{m}=-(\ln \Phi)^{-1}$ according to Matsumoto (1985). We implemented the Schwarz and Arnason parameterization of the Jolly-Seber model (Schwarz \& Arnanson, 1996) to estimate the abundance of $O$. germanica adults on each sampling occasion. This approach also provides an estimate of the total number of individuals during one season. The estimates of abundances were calculated using the POPAN software incorporated in program MARK (White \& Burnham, 1999). We used the values of the best selected model, which assumes a constant capture probability and temporal variation in the apparent survival probability $(\Phi)$ and probability of entry (pent) between sampling occasions.

We tested the effect of temperature on $O$. germanica's survival rate using linear mixed models (LMM) constructed in software R 3.0.1. (R Core Team, 2013). As our study involved repeated measurements in time, we used the LMM in order to be able to 


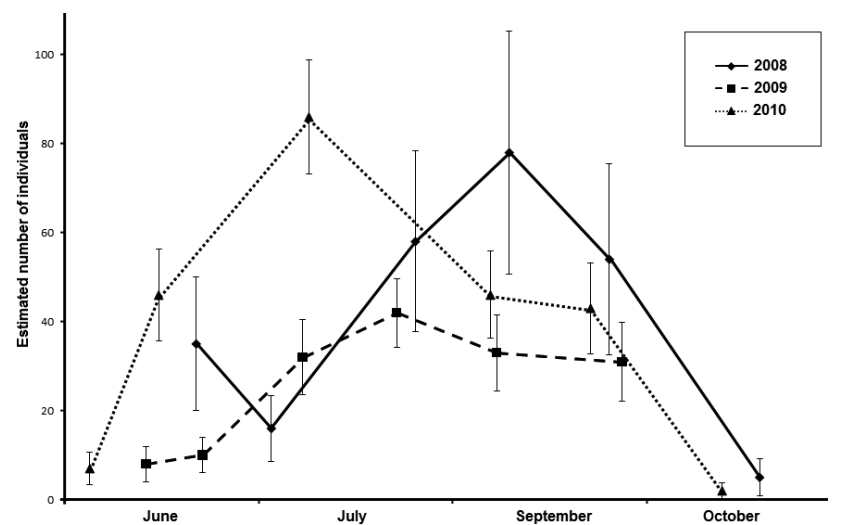

Fig. 4. Estimated numbers of individuals of $O$. germanica at the locality studied in each of the 3 years of this study. Value for each sampling occasion is given along with the standard error.

analyse all the data collected during this study together. The daily survival rate for each sampling period (i.e. a period between 2 sampling occasions; there were 6 sampling periods in each year) entered the analysis as a dependent variable, and the date of sampling nested within the year as a covariable (random effect) with the temperature values as predictors (fixed effect). We tested the effects of mean temperature (sum of mean daily temperatures in a sampling period divided by a number of days in the period) and mean of maximum temperatures (sum of maximum daily temperatures in a sampling period divided by a number of days in the period) separately. The residuals of the dependent variable were tested using t-statistic with Bonferonni correction in order to pinpoint the outliers, which led to exclusion of one value (test value $-2.144 ; p=0.032$ ). The most appropriate transformation of predictors was selected by stepwise regression on the basis of the lower AIC (Akaike information criterion) value. Statistical significance of individual factors was tested using F-tests. In the LMM, separate regression coefficients were tested using t-tests.

\section{RESULTS}

The estimated total population size at the locality was 136 (SE 28.5) adults in 2008, 70 (SE 8.5) in 2009 and 122 (SE 12.7) in 2010. The difference in the population size between 2008 and 2009 was about 49\%, which indicates the population fluctuates from year to year. The trends in the population sizes of $O$. germanica recorded in the different years are depicted in Fig. 4. The maximum recorded live span of adults was 101 days, which was for a female marked on the $5^{\text {th }}$ of July 2010 and recaptured for the last time on the $14^{\text {th }}$ of October 2010 (note that it was the only individual observed on that sampling occasion).

Mean daily survival rate was 0.950 in 2008, 0.970 in 2009 and 0.987 in 2010. This entails an estimated average residence time (number of days alive) of 19 days in 2008, 32 days in 2009 and 76 days in 2010. The results of the LMMs indicate a significant positive effect of both mean temperature and maximum temperature (i.e. mean of maximum temperatures) in a sampling period on the daily survival rate of $O$. germanica adults (Table 2). Used values of temperatures with their standard errors are given in Table 1.

\section{DISCUSSION}

Over a period of three years (2008-2010) we studied an isolated population of $O$. germanica on Koštál Hill, in the Czech Republic. The size of the population was relatively small and fluctuating. We documented a positive relationship between temperature and survival of $O$. germanica adults for the first time. Based on our and other authors' findings, we propose several ways of improving the conservation of this endangered species.

\section{Population of Oedipoda germanica}

The estimated total population size in each of the three years was about 100 individuals with high inter-seasonal fluctuations (difference in the population size between the years 2008 and 2009 was 49\%). Minimum viable population (MVP) for most animal species is reported to be a few thousand individuals (Traill et al., 2007) and for insects even over 10,000 individuals (Griebeler \& Gottschalk, 2000; Traill et al., 2007). Based on this, the size of the population studied is very small and potentially at a high risk of extinction. This is not in accordance with the finding of Wagner (2000), who calculated an MVP for O. germanica of only 20-80 females (or 40-160 individuals) which should provide a population survival probability of $95 \%$ over 20 years. Although the MVP can vary substantially across species and even populations (Flather et al., 2012; Jamieson \& Allendorf, 2012), Wagner's estimate seems to be too optimistic. First, his results evidently refer to the effective population size, which usually includes only a small proportion of the whole population (Frankham, 1995). Secondly, his model used population values obtained under laboratory conditions, but survival in wild populations exposed to more variable conditions may be lower. Thirdly, an attempt to re-establish $O$. germanica in a suitable habitat near Jena ended by extinction of population with just slightly less initial level than Wagner's MVP (19 females) after 3 years (Wagner, 2000; Wagner et al., 2005).

Near its northern limit, O. germanica is found in small populations, usually below 300 individuals (Niehuis, 1991; Hess \& Ritschel-Kandel, 1992; Sander, 1995; Zöller, 1995; Meineke \& Menge, 1997; Klingelhöfer, 1998; Maier, 2003; Klusáčová, 2013; this study) or possibly around 1000 individuals (population in Steudnitz, see Wagner, 2000), which are well below the generally accepted MVPs

TABLE 2. Linear mixed models (LMM) of the effect of temperature on the daily survival rate of adults of $O$. germanica.

\begin{tabular}{lccccr}
\hline & Regression coefficient & Standard error & Df & t-value & p-value \\
\hline Intercept & 0.878 & 0.039 & 8 & 22.020 & $<0.001$ \\
Mean temperature & 0.006 & 0.002 & 8 & 2.416 & 0.042 \\
Intercept & 0.870 & 0.043 & 8 & 20.192 & $<0.001$ \\
Max. temperature & 0.005 & 0.002 & 8 & 2.429 & 0.041 \\
\hline
\end{tabular}


for insects (Traill et al., 2007). At all of these peripheral localities, $O$. germanica occurs on isolated islands of specific thermophilic habitats, (Zöller, 1995; Wagner, 2000; Maier, 2003; Reinhardt et al., 2005), its dispersal ability is low (Zöller, 1995; Wagner, 2000) and the area of suitable habitat at these localities is very small, often below 1 ha (e.g. Wagner, 2000; Maier, 2003; Klusáčová, 2013). Thus populations of $O$. germanica near the northern limits of its range are similar and thus conservationists in Central Europe face the same problems when protecting this species. Many $O$. germanica populations in Central Europe went extinct during the $20^{\text {th }}$ century (Köhler \& Wagner, 2000; Wagner, 2000; Reinhardt et al., 2005; Holuša et al., 2009) and the threat of extinction remains for the rest of the populations.

\section{Effect of temperature on survival and implications for Oedipoda germanica conservation}

Our results indicate that the survival of $O$. germanica is very dependent on temperature (Table 2). Temperature is an important factor for grasshoppers as the whole of the Acrididae generally are thermophilic (Ingrisch \& Köhler, 1998b). O. germanica is especially thermophilic (Zöller, 1995). Wagner (2000) reports that its eggs require 173 degree-days above $15^{\circ} \mathrm{C}$ to complete their development and the nymphs require high temperatures to grow. Wagner et al. (2005) point out, that both microclimatic temperatures and macroclimatic long-term temperatures are of particular importance for $O$. germanica. Our results are therefore in agreement with previous findings and extend them. To the best of our knowledge, this is the first report of the influence of temperature on the survival of $O$. germanica adults. We recorded a significantly positive relationship between temperature and the survival rate of $O$. germanica adults.

Shading of the vegetation modifies the microclimate unfavourably because the ground under such vegetation is cooler than unshaded ground (Monteith, 1975; Runyan et al., 2012) and therefore can adversely affect temperature-dependent survival. The overgrowing of localities due to changes in land use is considered to be a leading cause of local extinction or endangerment of $O$. germanica (e.g. Hess \& Ritschel-Kandel, 1992; Zöller, 1995; Köhler \& Wagner, 2000; Holuša et al., 2009). Consequently, in agreement with other authors (Niehuis, 1991; Hess \& Ritschel-Kandel, 1992; Zöller, 1995; Maier, 2003), we recommend the removal of trees and shrubs from overgrown localities and subsequent control of succession. Grazing by goats and sheep, which in the past probably resulted in substantially larger areas of suitable habitat, is possibly the most suitable way of achieving this.

$O$. germanica is a rare habitat specialist with a low dispersal ability and therefore very susceptible to extinction (Reinhardt et al., 2005). Hence, this species deserves the attention of nature conservationist. An important part of O. germanica conservation is the preservation of isolated peripheral populations, which may have unique genetic adaptations (but see Reinhardt \& Köhler, 2002) for survival in the less favourable conditions at the edges of its distribution. Thus, even the relatively small population as on Koštál Hill should have a high priority in terms of conservation.

ACKNOWLEDGEMENTS. We are grateful to V. Beran, P. Moravec, O. Štěpán, I. Štěpánová, V. Štěpán, A. Véle, B. Honců, A. Ernst and M. Paclík for their helpful assistance with field work and data collection, to J. Trombik for his help in the preparation of the map showing the occurrence of $O$. germanica and to Ana Gouveia and A.F.G. Dixon for English language editing of the manuscript. Last but not least we thank the editor and a reviewer for their useful comments and advice. The research was partially supported by an internal grant from Palacký University number IGA PrF 2015 008 .

\section{REFERENCES}

ČEJCHAN A. 1980: [On the knowledge of orthopteroid insects (s.1.) of ČSSR.] - Čas. Nár. Muz. Praha 149: 125-139 [in Czech, English abstr.].

Flather C.H., Hayward G.D., Beissinger S.R. \& Stephens P.A. 2011: Minimum viable populations: is there a 'magic number' for conservation practitioners? - Trends Ecol. Evol. 26: 307-316.

FrANKHAM R. 1995: Effective population size/adult population size ratios in wildlife: a review. - Genet. Res. 66: 95-107.

Griebeler E.M. \& GotTschalk E. 2000: An individual based model of the impact of suboptimal habitat on survival of the grey bush cricket, Platycleis albopunctata (Orthoptera: Tettigoniidae). - J. Insect Conserv. 4: 225-237.

Heller K.-G., Korsunoviskaya O., Ragge D.R., Vedenina V., Willemse F., Zhantiev R.D. \& Frantsevich L. 1998: Checklist of European Orthoptera. - Articulata 7: 1-61.

Hess R. \& Ritschel-Kandel G. 1992: Die Beobachtung der Rotflügeligen Ödlandschrecke (Oedipoda germanica) in Unterfranken als Beispiel für das Management einer bedrohten Art. - Abh. Naturwiss. Ver. Würzburg 33: 75-102.

HolušA J. \& KoČÁREK P. 2005: Orthoptera. In Farkač J., Král D., Škorpík M. (eds): Red List of Threatened Species in the Czech Republic. Invertebrates. Agentura ochrany prrírody a krajiny ČR, Praha, pp. 133-134 [in Czech, English abstr.].

Holuša J., Marhoul P., ŠtěPÁNovÁ L. \& KoČÁreK P. 2009: Occurrence of red winged grasshopper Oedipoda germanica (Orthoptera: Acridiidae) in the Czech Republic. - Acta Mus. Mor. (Sci. Biol.) (Brno) 94: 15-21.

INGRISCH S. \& KöHLER G. 1998a: Rote Liste der Geradfluügler (Orthoptera s.1.). In Binot M., Bless R., Boye P., Gruntke H. \& Pretscher P. (eds): Rote Liste Gefährdeter Tiere Deutschlands. Schriftenreihe für Landschaftspflege und Naturschutz, BfN, Bonn-Bad Godesberg, pp. 252-254.

INGRISCH S. \& KÖHLER G. 1998b: Die Heuschrecken Mitteleuropas. Westarp Wissenschaften, Magdeburg, 460 pp.

Jamieson I.G. \& AlLendorf F.W. 2012: How does the 50/500 rule apply to MVPs? - Trends Ecol. Evol. 27: 578-584.

JohANNESSON K. \& ANDRÉ C. 2006: Life on the margin: genetic isolation and diversity loss in a peripheral marine ecosystem, the Baltic Sea. - Mol. Ecol. 15: 2013-2029.

KlingelHöFer J. 1998: Populationsgrößenschätzung bei Feldheuschrecken - ein Methodenvergleich. Diploma thesis, University of Jena.

Klusáčová M. 2013: [Population Ecology of the Red-winged Grasshopper (Oedipoda germanica) in the Area of the Capital City Prague.] Diploma thesis, Czech University of Life Sciences, Prague, 58 pp. [in Czech, English abstr.].

KÖHLER G. \& WAGNER G. 2000: Lebensräume der Rotflügeligen Ödlandschrecke, Oedipoda germanica (Latr.), und ihre Verge- 
sellschaftung mit anderen Heuschreckenarten in Thüringen. Mauritiana (Altenburg) 17: 389-416.

Kuncová J. ET AL. 1999: Ústecko. In Mackovčin P. \& Sedláček M. (eds): [Protected Areas of the Czech Republic, Vol. 1.] Agentura ochrany prírody a krajiny a Ekocentrum Brno, Praha, 808 pp. [in Czech].

Lebreton J.-D., Burnham K.P., Clobert J. \& Anderson D.R. 1992: Modelling survival and testing biological hypothesis using marked animals: a unified approach with case studies. Ecol. Monogr. 62: 67-118.

Lesica P. \& Allendorf F.W. 1995: When are peripheral populations valuable for conservation? - Conserv. Biol. 9: 753-760.

Maas S., Detzel P. \& Staudt A. 2002: Gefahrdungsanalyse der Heuschrecken Deutschland. Verbreitungsatlas, Gefahrdungseistufung und Schutzkonzepte. Bundesamt fur Naturschutz, Bohn-Bad Godesberg, $401 \mathrm{pp}$.

MAIER C. 2003: Untersuchungen zur Populationsentwicklung von Oedipoda germanica (Latr.) im Naturdenkmal "Galgenberg", Main-Tauber-Kreis (Caelifera: Acrididae). — Articulata 18: 193-208.

Matsumoto K. 1985: Population dynamics of the Japanese Clouded Apollo Parnassius glacialis Butler (Lepidoptera: Papilionidae). I. Changes in population size and related population parameters for three successive generations. - Res. Popul. Ecol. 27: 301-312.

MeineKe T. \& Menge K. 1997: Rotflügelige Ödlandschrecke und Rotflügelige Schnarrschrecke am Kleinen Bienstein im Jonastal bei Arnstadt (Ilmkreis). Populationen nach Durchführung von Pflegemaßnahmen. Schlußbericht an die Untere Naturschutzbehörde Ilmkreis. Arnstadt.

Monteith J.L. 1975: Vegetation and the Atmosphere: Principles. Academic Press, London, $298 \mathrm{pp}$.

NieHUIS M. 1991: Ergebnisse aus drei Artenschutzprojekten "Heuschrecken" (Orthoptera: Saltatoria). - Fauna Flora Rheinland-Pfalz 6: 335-551.

Pollock K.H., Nichols J.D., Brownie C. \& Hines J.E. 1990: Statistical inference for capture-recapture experiments. - Wildlife Monogr. 107: 1-97.

R Core Team 2013: R: A Language and Environment for Statistical Computing. R Foundation for Statistical Computing, Vienna.

ReINHARDT K. \& KöHLER G. 2002: Conservation of the red-winged grasshopper, Oedipoda germanica (Latr.): the influence of reproductive behaviour. - Biol. Conserv. 107: 221-228.

Reinhardt K., Kohler G., MaAs S. \& Detzel P. 2005: Low dispersal ability and habitat specificity promote extinctions in rare but not in widespread species: the Orthoptera of Germany. Ecography 28: 593-602.
Runyan C.W., D’Odorico P. \& Lawrence D. 2012: Physical and biological feedbacks of deforestation. - Rev. Geophys. 50: $1-32$.

SANDER U. 1995: Beziehungen zwischen Habitatparametern und Struktur und Größe von Populationen der Heuschreckenarten Oedipoda caerulescens (L., 1758) und Oedipoda germanica (Latr., 1804) im Mittelrheintal. Diploma thesis, University of Bonn, $181 \mathrm{pp}$.

SChWARZ C.J. \& ARnASOn A.N. 1996: A general methodology for the analysis of capture-recapture experiments in open populations. - Biometrics 52: 860-873.

SOULÉ M. 1973: The epistasis cycle: a theory of marginal populations. - Annu. Rev. Ecol. Syst. 4: 165-187.

Thomas J.A., Simcox D.J., Wardlaw J.C., Elmes G.W., Hochberg M.E. \& ClaRKE R.T. 1998: Effects of latitude, altitude and climate on the habitat and conservation of the endangered butterfly Maculinea arion and its Myrmica ant hosts. - J. Insect Conserv. 2: 39-46.

Thorens P. \& Nadig A. 1997: Atlas de Distribution des Orthoptères de Suisse. Sauterelles, Grillons, Criquets (Orthoptera), et Mante Religieuse (Mantodea). Centre Suisse de Cartographie de la Faune, Neuchâtel, 236 pp.

Traill L.W., Bradshaw C.J.A. \& Brook B.W. 2007: Minimum viable population size: a metaanalysis of 30 years of published estimates. - Biol. Conserv. 139: 159-166.

Wagner G. 2000: Eine Populationsgefährdungsanalyse der Rotflügeligen Ödlandschrecke, Oedipoda germanica (Latr. 1804) (Caelifera: Acrididae). - Articulata 9: 1-118.

WAgner G. \& Berger U. 1996: A population vulnerability analysis of the red-winged grasshopper, Oedipoda germanica (Latreille) (Caelifera: Acrididae). In Settele J., Margules C., Poschlod P. \& Henle K. (eds): Species Survival in Fragmented Landscapes. Kluwer, Dordrecht, pp. 312-319.

Wagner G., KöHLer G., Berger U. \& Davis A.J. 2005: An experiment to re-estabilish the red-winged grasshopper, Oedipoda germanica (Latr.) (Caelifera, Acrididae), threatened with extinction in Germany. - J. Nat. Conserv. 13: 257-266.

White G.C. \& Burnham K.P. 1999: Program MARK: Survival estimation from populations of marked animals. - Bird Study 46: $120-139$.

ZöLLER S. 1995: Untersuchungen zur Ökologie von Oedipoda germanica (Latreille, 1804) unter besonderer Berücksichtigung der Populationsstruktur, der Habitatbindung und der Mobilität. - Articulata 10: 21-59.

Zuna-KratKy T. 2011: Heuschrecken Österreich 2011. Accessible online: http://bit.ly/17fTy05.

Received November 19, 2014; revised and accepted April 27, 2015 Prepublished online May 15, 2015 